\title{
The Advancement of Science and Society
}

\section{Proposed World Association}

$\mathrm{A}^{\mathrm{T}}$ T the recent Indianapolis meeting of the American Association for the Advancement of Science, two important resolutions were adopted unanimously by the Council and may have profound effects, not only upon the future of science, but also upon social history. The resolutions propose, in effect, the setting up of a scientific 'brains trust' for the world, and proclaim the democratic principles of science, and the intellectual freedom of scientific workers ; and they denounce totalitarian suppression as a major crime against civilization.

This action may be said to have had its origin in a movement, started several years ago, and strongly supported by NATURE, to make the British Association the platform for the discussion of social problems which science had helped to create and might help to solve. By the time of the Blackpool meeting in 1936, the success of the British Association in this field was manifest. The American delegates, led by Prof. E. G. Conklin, were greatly impressed by the spirit of the meeting. They wanted to hear the men of science of the United States speak as freely, and constructively, on social issues.

Among the American visitors was Mr. Waldemar Kaompffert. Mr. Ritchie Calder, who had already discussed the ideas with leading British men of science, proposed with Mr. Kaempffert 'A Magna Charta of Science'-a declaration of independence, declaring the free, democratic, altruistic principles of science, and also the formation of an Anglo-American concord, as the nucleus of a world organization for all who would subscribe to, and advance, these principles. Together, they saw Prof. Conklin, who wholeheartedly approved, and Sir Josiah Stamp. Coincidentally, Prof. Etienne Gilson, professor of the history of philosophy in the Middle Ages in the Collège de France, was proposing, at the Harvard tercentenary, the setting up of a 'Supreme Court of Science' for the world.

The British Association, during 1937, entered into negotiation with the American Association for collateral membership and exchange of publications, but the major proposals were deferred. In October 1937, however, the New York Times published a leading article on an open letter which Mr. Ritchie Calder had addressed, in the Daily Herald, to Lord Rayleigh, reviving the proposals. The response in the United States was immediate. Dr. F. R. Moulton, executive secretary of the American Association, made the proposals the basis of his address last December to the Council, in which he also proposed that the American Association should invite lay members, mostly from the universities, to the number of one hundred thousand. The symposium on science and society, Prof. Conklin's inspiring address on science and ethics (see Nature, Jan. 15), and Dr. Moulton's appeal assured the enthusiastic reception of the proposals. On December 30, the Council of the Association responded by unanimously endorsing the following resolutions :

"Whereas, science and its applications are not only transforming the physical and mental environment of men, but are adding greatly to the complexities of the social, economic and political relations among them; and
"Whereas, science is wholly independent of national boundaries and races and creeds and can flourish permanently only where there is peace and intellectual freedom : now

"Therefore, Be it resolved by the council on this thirtieth day of December 1937, that the American Association for the Advancement of Science makes as one of its objectives an examination of the profound effects of science upon society ; and that the Association extends to its prototype, the British Association for the Advancement of Science, and to all other scientific organizations with similar aims throughout the world, an invitation to co-operate, not only in advancing the interests of science, but also in promoting peace among nations and intellectual freedom in order that science may continue to advance and spread more abundantly its benefits to all mankind."

The Association at the same time reaffirmed a resolution on intellectual freedom, originally presented by Dr. Robert A. Millikan and Prof. Henry Norris Russell. The Millikan-Russell resolution, incorporated in the new declaration, reads :

"The American Association for the Advancement of Science feels grave concern over persistent and threatening inroads upon intellectual freedom which have been made in recent times in many parts of the world.

"Our existing liberties have been won through ages of struggle and at enormous cost. If these are lost or seriously impaired there can be no hope of con. tinued progress in science, or justice in Government, of international or domestic peace, or even of lasting material well-being.

"We regard the suppression of independent thought and of its free expression as a major crime against civilization itself. Yet oppression of this sort has been inflicted upon investigators, scholars, teachers and professional men in many ways, whether by government action, administrative coercion or extra-legal violence.

"We feel it our duty to denounee all such actions as intolerable forms of tyranny.

"There can be no compromise on this issue, for even the commonwealth of learning cannot endure 'half slave and half free'. By our life and training as scientists and by our heritage as Americans we must stand for freedom."

As one of the first steps to create the machinery, Dr. Moulton was requested by the council "to take up with the British Association the question of the desirability of inviting its members to join the American Association", so that the combined scientific forces of America and Great Britain should act as a "united world intellect".

Another gesture, which was warmly received by the American men of science, was the announcement made by Sir William Bragg in his presidential address to the Royal Society on November 30 last that the National Academy of Sciences of the United States of America and the Royal Society of London had arranged for the exchange of lectureships between the two democracies in alternate years. An account of this endowment by the Pilgrim Trust was given in NATURE of December 4, 1937 (140, 961). 